\title{
Analisis Tingkat Perkembangan Akuifer Karst di Kawasan Karst Gunung Sewu, Daerah Istimewa Yogyakarta dan Karst Rengel, Tuban, Jawa Timur Berdasarkan Analisis Hidrograf
}

\author{
Tjahyo Nugroho Adji, M. Asyroful M ujib, Hendy Fatchurohman, Igor Yoga Bahtiar ${ }^{1}$
}

\begin{abstract}
Abstrak
Tingkat perkembangan karstifikasi (derajat karstifikasi) suatu akuifer karst mempengaruhi karakteristik imbuhan airtanah, besar sedikitnya kapasitas simpanan dan sistem pelepasan air oleh akuifer. Akuifer karst yang memiliki derajat karstifikasi tinggi akan memiliki kapasitas simpanan air yang rendah dan sistem pelepasan air yang cepat, sebaliknya pada akuifer karst yang memiliki derajat karstifikasi rendah akan didominasi oleh tipe aliran diffuse, kapasitas simpanan akuifer tinggi dan sistem pelepasan simpanan airnya yang perlahan. Tujuan penelitian ini adalah untuk mengidentifikasi secara spasial dan temporal derajat karstifikasi pada suatu akuifer karst berdasarkan karakteristik hidrograf alirannya.

Penelitian ini dilakukan pada dua mataair (Beton dan Petoyan) dan enam sungai bawah tanah (Bribin, Gilap, Ngreneng, Seropan, Toto, dan Ngerong) pada dua kawasan karst yang berbeda yaitu Karst Gunung Sewu, Gunung Kidul, Yogyakarta dan Karst Rengel, Kabupaten Tuban, Jawa Timur. Data utama yang digunakan adalah data perekaman tinggi mukaair secara time series yang kemudian dikonversikan menjadai data debit aliran setelah dibuat stage discharge rating curve-nya pada ke delapan lokasi pengukuran. Metode straight line methods kemudian dilakukan untuk memisahkan komponen aliran dasar, dan analisis hidrograf berdasarkan rumus Rashed (2012) dilakukan untuk mengukur seluruh komponen hidrograf untuk menentukan derajat karstifikasi akuifer karstnya.

Hasil penelitian menunjukkan bahwa secara temporal terdapat perbedaan derajat karstifikasi pada awal musim penghujan berupa darcian aquifer $\left(D_{k}=1.95-9.27\right)$, meningkat menjadi partially dan karstified aquifer $\left(D_{k}=10.92-35.99\right)$ pada pertengahan musim, dan di akhir musim penghujan derajat karstifikasi menurun kembali menjadi darcian aquifer. Secara spasial, terdapat perbedaan derajat karstifikasi antara di bagian hulu sistem SBT Bribin (Gua Gilap dan Mataair Beton) yaitu pada tahap partially dan karstified akuifer dan di bagian hilir (Gua Bribin, Seropan, dan Toto) pada tahap darcian aquifer. Secara umum, perhitungan pada awal dan akhir musim hujan menunjukkan bahwa Karst Gunung Sewu dan Karst Rengel termasuk pada derajat karstifikasi Darcian aquifer, yaitu Karst Rengel berada pada darcian aquifer tahap 1 (muda), sedangkan Karst Gunung Sewu berada pada darcian aquifer tahap 2 (tua). Sementara itu, perhitungan saat banjir pada puncak musim hujan menunjukan bahwa karstifikasi di Karst Gunung Sewu telah lebih berkembang disbanding dengan Karst Rengel.
\end{abstract}

Kata kunci : Derajat karstifikasi, analisis hidrograf, akuifer karst

\footnotetext{
${ }^{1}$ Fakultas Geografi, Universitas Gadjah Mada.
} 


\section{Pendahuluan}

Akuifer karst memiliki karakteristik hidrogeologi yang kompleks dan khas dibandingkan dengan akuifer yang lain, diantaranya memiliki tiga sifat porositas (triple porosity) yaitu diffuse, fissure, dan conduit; tingkat heterogenitas yang tinggi dan anisotropis; serta konduktifitas hidraulik yang tinggi (White and Elizabeth, 2003; Ford and William, 2007). Seiring dengan berkembangnya porositas sekunder yang berupa lorong-lorong conduit dalam suatu akuifer karst, akan semakin tua pula umur suatu kawasan karst atau dengan kata lain semakin lanjut pula derajat karstifikasinya (Haryono dan Adji, 2004). Proses karstifikasi ini secara umum dikontrol oleh faktor geologi, iklim, hidrologi, dan vegetasi (Daoxian, 2013), Lebih khusus, karstifikasi yang berkembang di kawasan karst tropis dipengaruhi oleh faktor curah hujan yang tinggi, temperatur hangat, lebatnya vegetasi sehingga konsentrasi $\mathrm{CO}_{2}$ tinggi dan besarnya potensi aliran airtanah (Nguyet, 2006).

Tingkat perkembangan karstifikasi ini sangat menentukan sifat akuifer dalam melepaskan simpanan airnya. Semakin tinggi proses karstifikasi, saluran conduitakan semakin berkembang dengan konduktivitas hidraulik tinggi dan sifat aliran cepat, sedangkan semakin rendah tingkat perkembangan karstifikasi, aliran akan didominasi oleh tipe diffuse dengan konduktivitas hidraulik rendah dan sifat aliran lambat (Baena et al., 2009). Oleh karena itu, derajat karstifikasi berperan secara mendasar untuk manajemen sumberdaya air berkelanjutan.

Berbagai metode penelitian telah banyak dilakukan untuk mengklasifikasi tingkat perkembangan akuifer karst di antaranya (1) analisis hidrokemograf, yakni dengan memantau variasi kualitas air di sebuah mataair karst (Shuster and White, 1971; Raeisi and Karami, 1997; Lastennet and Mudry, 1997; Adji, 2005; Adji, 2012) (2) analisis sistem linear (Dreiss, 1989); (3) rasio heterogenitas; (4) analisis resesi hidrograf banjir (Adji and M isqi, 2010; Adji et al, 2009; Adji 2011); dan (5) kecepatan akuifer karst dalam melepaskan air (aquifer flashiness). Diantara kelima metode diatas, analisis resesi hidrograf banjir pada mataair dan sungai bawah tanah karst dianggap mampu memberikan informasi terkait kondisi internal, karakteristik, sistem aliran dan mencerminkan kondisi daerah imbuhan akuifer karst (Bonacci, 1993; Kresic dan Bonacci, 2010; Mohammadi, 2013). Rashed (2012) juga memperkenalkan metode baru dengan menggunakan seluruh komponen hidrograf (rising and recession limb, time to peak, time to baseflow, and time event) dalam menentukan derajat karstifikasi suatu akuifer karst.

Penelitian ini bermaksud untuk melakukan investigasi secara spasial dan temporal terkait derajat karstifikasi suatu akuifer karst melalui pendekatan pada karakteristik hidrograf aliran berdasarkan rumus Rashed (2012). Berdasarkan pendekatan hidrograf aliran pada saat awal, tengah, dan akhir musim penghujan, penelitian ini akan diterapkan di dua mataair (Beton dan Petoyan) dan lima sungai bawah tanah (Bribin, Gilap, Nggreneng, Seropan, dan Toto) yang terdapat di Karst Gunung Sewu bagian selatan Pulau Jawa, dan satu sungai bawah tanah (Ngerong) yang terdapat di Karst Rengel, Tuban di bagian utara Pulau Jawa untuk melihat perbandingan derajat karstifikasi pada dua kawasan karst tersebut.Lokasi penelitian ditunjukkan pada Gambar 1. 


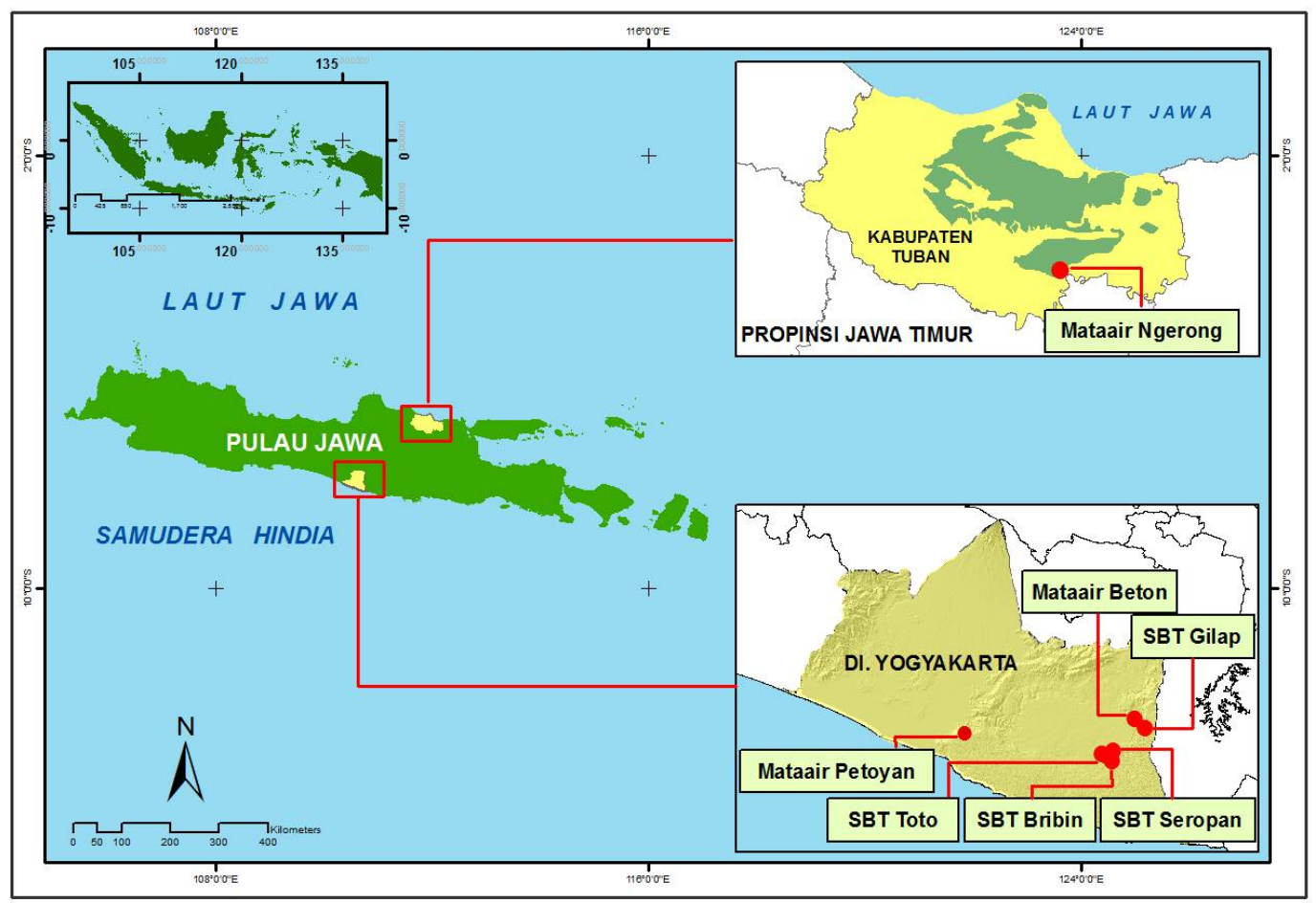

Gambar 1.Lokasi daerah penelitian (Karst Gunung Sewu, DIY dan Karst Rengel, Kab. Tuban, Jawa Timur)

\section{Karakteristik Umum Daerah Penelitian}

Penelitian ini diterapkan pada dua kawasan karst yang berkembang pada formasi batuan, umur geologi, dan kenampakan topografi karst yang berbeda, yaitu (1) Kawasan Karst Gunung Sewu, Kabupaten Gunung Kidul, Yogyakarta; dan (2) Kawasan Karst Rengel, Kabupaten Tuban, Jawa Timur. Kawasan Karst Gunung Sewu berada pada Formasi Wonosari yang tersusun dari batugamping berlapis, batugamping masif, dan batugamping terumbu (Brunsch, et al, 2011). Ciri khusus pada formasi ini adalah dominasi porositas sekunder berupa rongga-ronga hasil pelarutan. Struktur geologi Kawasan Karst Gunung Sewu secara umum merupakan homoklin yang miring ke selatan dengan sudut lereng $5^{\circ}$ $15^{\circ}$. struktur retakan menunjukkan arah jurus umum barat laut-tenggara dan timur lautbaratdaya (Kusumayudha, 2005). Kenampakan geomorfologi dalam kawasan ini diungkapkan lebih komprehensif oleh Haryono and Day (2004) yang terdiri dari morfologi karst labirin; morfologi karst poligonal yang mendominasi daerah selatan; dan morfologi karst tower yang mendominasi daerah utara hingga tengah.

Mataair dan sungai bawah tanah di Karst Gunung Sewu dalam ruang lingkup penelitian ini antara lain (a) Mataair Beton (49 M 0469977; 9121249), terletak di Desa Umbulrejo,Kecamatan Ponjong, mataair tipe Perennial ini memiliki debit rata-rata 720 liter/detik dan debit minimum 505,9 liter/detik pada tahun 2009 (Adji, 2010; Misqi, 2010) serta telah dimanfaatkan oleh penduduk untuk keperluan domestik, irigasi sawah, dan tambak; (b) Mataair Petoyan, terletak di Desa Petoyan, Kecamatan Purwosari. Tahun 20122013 memiliki debit rata-rata 7,6 liter/detik dengan debit minimum 1,9 liter/detik dan maksimum 48,4 liter/detik. Mataair tipe Perennial ini telah dimanfaatkan untuk kebutuhan 
domestik; (c) Sungai bawah tanah Gua Gilap (49 M 472076; 9119137) terletak di Kecamatan Paliyan dengan panjang gua 1090 meter, berada di bagian hulu daerah tangkapan SBT Bribin dan diasumsikan mewakili SBT Bribin bagian atas, MacDonald and Partners (1984) menyebutkkan bahwa Gua Gilap selalu dialiri air sepanjang tahun dan memiliki debit minimum sebesar sekitar 6 liter/detik yang terjadi pada puncak musim kemarau. (d) Sungai bawah tanah Gua Ngreneng (49 M 463590; 9112961), berdasarkan hasil tracer test oleh MacDonald and Partners (1984), diketahui bahwa SBT Gua Ngreneng merupakan pemunculan sungai bawah tanah yang diyakini sebagai bocoran dari sungai utama Bribin. Gua ini terletak pada suatu cekungan bekas doline yang mempunyai beda tinggi sekitar 50 meter antara dasar sungai dan permukaan lembahnya. SBT tipe perennial ini pada saat musim hujan debit sungai dapat menjadi sangat tinggi karena pintu masuk gua ini juga berfungsi sebagai sinkhole aliran permukaan di sekitar cekungan gua ini yang mengakibatkan tingginya pasokan aliran permukaan. (e) Sungai bawah tanah Gua Seropan (49 M 0465025; 9113946) terletak di Dusun Semuluh Lor, Desa Ngepohsari, Kecamatan Semanu, berada pada ketinggian 203 mdpal dengan panjang gua 650 meter, Gua seropan selalu berair sepanjang tahun (Perennial) serta sistem perguaan yang masih aktif, debit rata-rata 875,7 It/dt, debit minimum 812,4 lt/dt dan debit maksimum $1184,5 \mathrm{lt} / \mathrm{dt}$. potensi sumberdaya air didalamnya telah dimanfaatkan oleh penduduk di desa-desa sekitar untuk kebutuhan domestik; (f) Sungai bawah tanah Gua Toto (49 M 0462421; 9113408) terletak di Dusun Wediutah, Desa Ngepohsari, Kecamatan Semanu, berada pada ketinggian 164 mdpal. Gua Toto selalu berair sepanjang tahun (perenial) dengan debit rata-rata 153,5 liter/detik, debit minimum 124,5 liter/detik dan maksimum 943,5 liter/detik, sayangnya potensi sumberdayaair didalamnya hingga saat ini masih belum dimanfaatkan oleh masyarakat sekitar; (g) Sungai bawah tanah Gua Bribin (49 M 464666;9111646) terletak di Kecamatan Semanu, mengalir sepanjang tahun (perennial) dengan debit rata-rata 800-900 liter/detik. Memiliki lorong gua sepanjang 3.900 meter, berada di bagian hilir dan dianggap sebagai pemunculan terakhir Sungai Bribin sebelum akhirnya muncul sebagai resurgence di Pantai Baron.

Mataair yang berada di Kawasan Karst Rengel dalam penelitian ini adalah Mataair Ngerong (49 M 611269; 9219516), terletak di terletak di Desa Rengel, Kecamatan Rengel, sekitar $30 \mathrm{~km}$ arah selatan Kota Tuban. Secara geologi Karst Rengel berada pada Formasi Paciran dengan litologi batugamping terumbu, terbentuk pada awal hingga pertengahan Miosen dan mulai tersingkap sejak akhir Pleistosen (Bemmelen, 1949). Sebaran Fasies batuan karbonat penyusun Formasi Paciran yang terdapat di Karst Rengel terdiri dari wackestone danboundstone, Karst Rengel dan sekitarnya merupakan antiklinal yang terkikis dengan arah jurus ke timur-barat dengan kemiringan semu sebesar $15^{\circ}$ (Haryono, dkk., 2001, 2008). Secara geomorfologi mataair ini berada di lereng kaki perbukitan Karst Rengel bagian selatan yang berbatasan dengan dataran alluvial Sungai Bengawan Solo. Mataair tipe perennial ini berada pada ketinggian 45 mdpal dan pada daerah imbuhan mataair dengan elevasi tertinggi mencapai 335 mdpal. Haryono (2008) mengungkapkan bahwa kenampakan eksokarst baik mayor maupun minor di Karst Rengel tidak berkembang dengan baik, kemiringan lereng berkisar antara 28\% hingga 33\%, sedangkan doline tidak 
berkembang dengan baik di wilayah ini.Karakteristik debit selama periode penelitian di tiap mataair dan sungai bawah tanah ditunjukkan pada Tabel 1 .

Tabel 1. Karakteristik debit mataair dan sungai bawah tanah daerah penelitian

\begin{tabular}{llrrr}
\hline \multicolumn{1}{c}{$\begin{array}{c}\text { Mataair dan } \\
\text { Sungai Bawah }\end{array}$} & \multicolumn{1}{c}{ Periode } & \multicolumn{3}{c}{ Debit (Q) liter/detik } \\
\cline { 3 - 5 } \multicolumn{1}{c}{ Tanah } & & Q min & Q max & Q mean \\
\hline Mataair Beton & Januari - September 2009 & 505,90 & 11111,70 & 1555,70 \\
Mataair Petoyan & Oktober 2012-Agustus 2013 & 1,95 & 48,49 & 7,62 \\
SBT Gilap & Mei 2006 - April 2007 & 3,00 & 380,00 & 47,31 \\
SBT Ngreneng & Mei 2006 - April 2007 & 60,00 & 1905,30 & 180,04 \\
SBT Seropan & Februari - Agustus 2009 & 812,40 & 1184,50 & 875,70 \\
SBT Toto & November 2008-September 2009 & 124,50 & 943,50 & 153,50 \\
SBT Bribin & Mei 2006 - April 2007 & 1630,00 & 2520,00 & 1771,11 \\
SBT Ngerong & Januari - Juli 2014 & 580,20 & 6407,90 & 968,50 \\
\hline Sumber: Hasil analisis data primer dan sekunder (2014) & & &
\end{tabular}

\section{Metode Penelitian}

Penelitian ini menggunakan pendekatan hidrograf aliran untuk menentukan derajat karstifikasi akuifer karst di daerah penelitian. Data yang dibutuhkan dalam penelitian ini antara lain (1) data tinggi muka air dari mataair dan sungai bawah tanah yang direkam secara time series dengan interval waktu perekaman 15 menit dan 30 menit menggunakan Hobo Water Level; dan (2) data debit yang diukur dengan metode sudden injection, pelampung, dan current meter sebagai dasar dalam pembuatan rating curve. Pengukuran debit dengan metode sudden injection adalah dengan menuangkan larutan dan mencatat perubahan nilai DHL dengan interval 10 detik hingga kembali mendekati nilai daya hantar listrik (DHL) awal, diformulasikan dalam Rumus 1.

$$
Q=\frac{V \times C_{1}}{T \times C_{2}}
$$

dimana $\mathrm{Q}$ adalah debit aliran ( $\mathrm{m}^{3} /$ detik), $\mathrm{V}$ adalah volume larutan yang dituang, $\mathrm{T}$ adalah waktu yang ditempuh oleh larutan, $C_{1}$ merupakan konsentrasi larutan yang dituang, dan $C_{2}$ adalah nilai rata-rata konsentrasi menuju kondisi awal.

Pengukuran debit menggunakan metode pelampung menggunakan Rumus 2

$$
Q=A \times k \times u
$$

dimana A adalah luas penampang basah $\left(\mathrm{m}^{2}\right), \mathrm{k}$ adalah koefisien pelampung yang nilainya tergantung pada jenis pelampung yang digunakan dan diformulasikan pada Rumus 3 , sedangkan $\mathrm{u}$ adalah kecepatan pelampung $(\mathrm{m} / \mathrm{dt})$.

$$
k \equiv 1-0.116(\sqrt{ }(1-\lambda)-0.1
$$

dengan $\lambda$ dihasilkan dari kedalaman tangkai (h) dibagi kedalaman air (d).

Pengukuran debit menggunakan alat pengukur kecepatan arus (current meter) dihitung berdasarkan jumlah putaran baling-baling (cup) per waktu putaran (N), kecepatan aliran dihitung dengan Rumus 4. 


$$
V=a \mathrm{~N}+\mathbf{b}
$$

dimana $\mathrm{V}$ adalah kecepatan pelampung $(\mathrm{m} / \mathrm{dt})$; a,b merupakan koefisien alat; dan $\mathrm{N}$ merupakan jumlah putaran per waktu

Tahapan-tahapan analisis untuk menentukan derajat karstifikasi akuifer yaitu pertama, menentukan debit aliran berdasarkan stage discharge rating curve, diartikan sebagai kurva yang menunjukkan hubungan antara tinggi muka air dengan debit terukur. Pengukuran debit dilakukan beberapa kali saat tinggi muka air rendah, sedang dan tinggi yang diharapkan dapat mewakili variasi debit dalam berbagai kondisi aliran. Rumus dari stage discharge rating curve ini sebagai rumus dasar dalam menentuan debit aliran sesuai fluktuasi tinggi muka airnya.

Kedua, adalah pemisahan aliran dasar yang dilakukan dengan metode straight line method, yakni dengan menggambar hidrograf pada skala logaritma, sebagaimana yang disajikan pada Gambar 2.

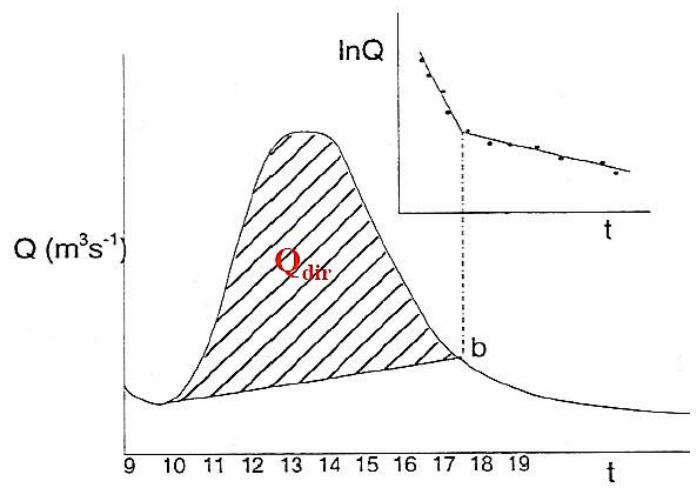

Gambar 2. Memisahkan Baseflow dengan straight line method

Ketiga, menghitung derajat karstifikasi $\left(D_{k}\right)$, Derajat karstifikasi ditentukan dengan mengaplikasikan formula yang diusulkan oleh Rashed (2012). M etode ini menggunakan data-data yang diambil dari sebuah hidrograf banjir sejak mulai debit naik hingga debit kembali lagi menjadi aliran dasar (baseflow), termasuk data waktu dimulainya banjir, waktu puncak, dan waktu kembali menjadi baseflow. Komponen hidrograf ini diformulasikan dalam Rumus 5 dan diilustrasikan pada Gambar 3.

$$
D_{k}=\frac{\frac{Q_{\max }}{Q_{\min } t_{\text {event }}}}{t_{\text {pask }}}
$$

Sedangkan $t_{\text {event }}$ dan $t_{\text {peak }}$ didapat dari

$$
\begin{gathered}
\mathbf{t}_{\text {avent }}=t_{C}-\mathbf{t}_{A} \\
\text { dan } \\
t_{\text {peak }}=t_{B}-\mathbf{t}_{A}
\end{gathered}
$$

dimana $Q_{\max }$ adalah debit maksimum di titik $B ; Q_{\min }$ merupakan debit minimum saat hidrograf mulai naik di titikA; $t_{A}$ adalah waktu ketika mulai menaiknya hidrograf; $t_{B}$ adalah waktu ketika debit maksimum terekam; dan $\mathrm{t}_{\mathrm{c}}$ merupakan waktu ketika hidrograf sudah mencapai baseflow kembali 


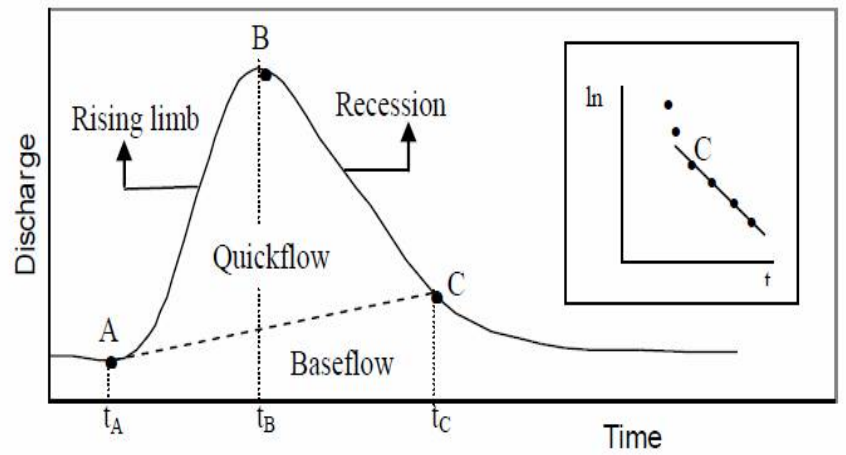

Gambar 3.Komponen hidrograf mataair karst yang digunakan untuk menghitung derajat karstifikasi (Rashed, 2012)

Nilai derajat karstifikasi $\left(D_{k}\right)$ hasil perhitungan Rumus 5 diklasifikasikan menjadi 5 kategori akuifer pada Tabel 2.

Tabel 2. Klasifikasi tingkat perkembangan akuifer karst

\begin{tabular}{cl}
\hline $\mathbf{D}_{\mathbf{k}}$ & Klasifikasi \\
\hline$<10$ & Akuifer yang sistemnya didominasi aliran diffuse (Darcian aquifer) \\
$10-20$ & Akuifer yang telah terkarstifikasi sebagian (Partially karstified aquifer) \\
$20-60$ & Akuifer yang telah terkarstifikasi (Karstified aquifer) \\
$>60$ & Akuifer yang telah terkarstifikasi secara lanjut (Highly karstified aquifer) \\
\hline Sumber : Rashed (2012)
\end{tabular}

Penelitian ini mengkaji lebih lanjut derajat karstifikasi berdasarkan variasi temporalnya antara saat awal, pertengahan dan akhir musim penghujan pada dua kawasan karst yang berbeda. Periode perekaman data mulai dari 6 bulan hingga 1 tahun dengan menggunakan data primer (Mataair Petoyan dan SBT Ngerong) dan data sekunder (Beton, Bribin, Gilap, Ngreneng, Seropan, dan Toto). Penentuan periode awal, pertengahan, dan akhir musim hujan tiap tahunnya senantiasa tidak sama, sehingga dalam penelitian ini awal musim penghujan diasumsikan antara bulan desember-januari; pertengahan antara bulan februarimaret; dan akhir musim penghujan antara bulan april-mei. Tiap periode tersebut dipilih dua hidrograf banjir yang mewakili kondisi aliran yang berbeda (tinggi, sedang, dan rendah), memiliki kondisi baseflow normal sebelum mulai rising limb, dan waktu resesi yang cukup lama untuk kemudian bisa dihitung nilai derajat karstifikasinya.

\section{Hasil dan Pembahasan}

\section{Hidrograf dan Pemisahan Aliran Dasar}

Pengukuran debit mataair dan sungai bawah tanah dilakukan pada beberapa variasi tinggi muka air rendah, sedang, hingga tinggi untuk mendapatkan konstanta dasar dalam menentukan debit aliran berdasarkan variasi tinggi muka airnya. Debit dan tinggi mukaair 
yang terukur dianalisis dengan stage discharge rating curve sehingga didapatkan konstanta pada tiap mataair dan sungai bawah tanah (Tabel 3), dimana y adalah debit aliran (liter/detik) dan $\mathrm{x}$ adalah tinggi permukaan air (meter). Tinggi muka air yang telah terekam dalam satu periode penelitian dikonversi menjadi debit aliran menggunakan konstanta dari rating curve tersebut.

Tabel 3. Hasil analisis stage discharge rating curve di tiap lokasi penelitian

\begin{tabular}{lcl}
\hline Mataair dan SBT & Pengukuran debit & Rumus dari Rating Curve \\
\hline Mataair Beton & 17 kali & $\mathrm{y}=4449,6 \mathrm{x}^{2,3324}$ \\
Mataair Petoyan & 12 kali & $\mathrm{y}=94.591(\mathrm{x})+0.6292$ \\
SBT Gilap & 9 kali & $\mathrm{y}=7,9129 \mathrm{e}^{2,7173 x}$ \\
SBT Ngreneng & 9 kali & $\mathrm{y}=49,164 \mathrm{e}^{1.343 x}$ \\
SBT Seropan & 7 kali & $\mathrm{y}=1418,9 \ln (\mathrm{x})+557,22$ \\
SBT Toto & 9 kali & $\mathrm{y}=5500,3 \times 2-3007,9 \mathrm{x}+536,37$ \\
SBT Bribin & 15 kali & $\mathrm{y}=1204,5 \mathrm{x}^{1,0103}$ \\
SBT Ngerong & 20 kali & $\mathrm{y}=5.0196(\mathrm{x})-2.0501$ \\
\hline Sumber : Hasil analisis data primer dan sekunder $(2014)$
\end{tabular}

Debit yang terekam akan dapat menggambarkan seluruh hidrograf banjir dalam satu periode pencatatan data. Tidak semua hidrograf banjir dapat dianalisis dengan Rumus 5, sehingga dalam setiap periode awal, tengah, dan akhir musim hujan dipilih beberapa hidrograf banjir yang memenuhi kriteria untuk dianalisis lebih lanjut.

Bentuk hidrograf banjir terpilih tiap mataair dan sungai bawah tanah dapat dilihat pada Gambar 4 yang diselingi dengan metode pemisahan aliran dasar menggunakan straight line methods. Hidrograf yang dipilih mewakili banjir pada awal musim penghujan (kode banjir A), pertengahan musim penghujan (kode banjir B), dan akhir musim penghujan (kode banjir C).

Pemisahan aliran dasar menggunakan straight line methods pada tiap hidrograf menghasilkan titik pada kurva resesi yang memisahkan resesi quickflow dari resesi baseflow (separation point), titik ini sebagai batas dalam menghitung waktu dari debit puncak menuju aliran dasar (time to baseflow $=T_{b}$ ) dan waktu seluruh kejadian hidrograf (time event). Waktu menuju puncak banjir (Time to Peak $=T_{p}$ ), time to baseflow, dan time event merupakan parameter hidrograf yang paling mudah dikenali selain bentuk kurva hidrografnya. Rata-rata $T_{p}$ dan $T_{b}$ dari beberapa kejadian banjir di tiap mataair yang dijabarkan pada Tabel 4 menunjukkan kondisi hidrograf yang berbeda, Hal ini memang menunjukkan bahwa struktur rekahan akuifer yang mencirikan porositas diffuse, fissures dan conduit dalam akuifer karst bersifat heterogen dan anisotropis, sehingga dalam satu kawasan karst yang sama memiliki karakteristik yang berbeda dalam merespon input, menyimpan dan melepaskan simpanan akuifernya. Waktu tunda akuifer dalam merespon kejadian hujan dilihat dari parameter time to peak dan bentuk resesi hidrograf dilihat dari parameter time to baseflow merupakan indikator pertama dalam melihat kapasitas daerah imbuhan mataair dan transmisivitas akuifer (Kresic and Bonacci, 2010). 
Citation: PIT IGI ke-17, UNY, Jogjakarta, 15 Nov 2014 
Citation: PIT IGI ke-17, UNY, Jogjakarta, 15 Nov 2014

SBT Seropan

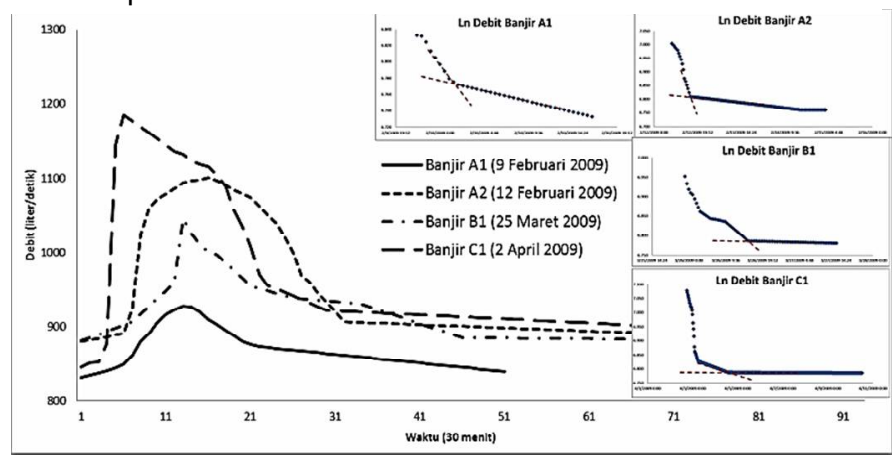

SBT Bribin

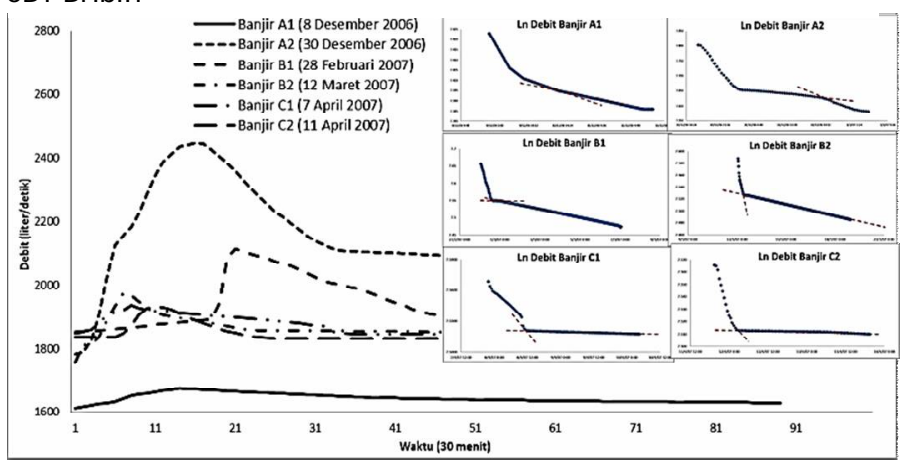

Mataair Beton

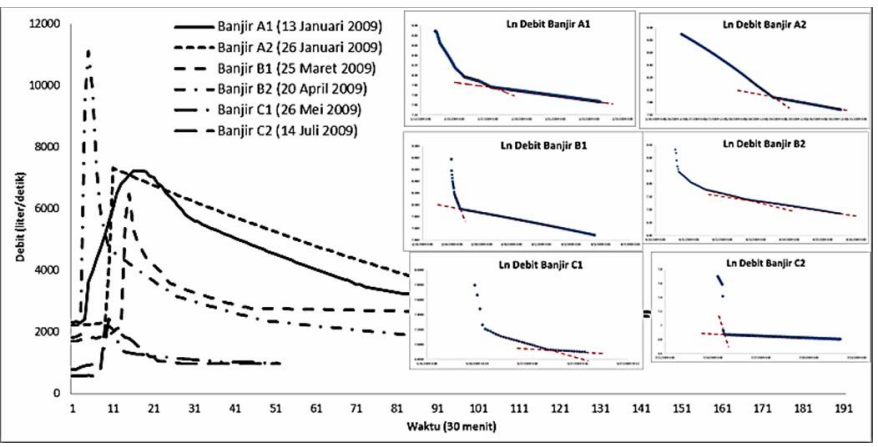

SBT Gilap

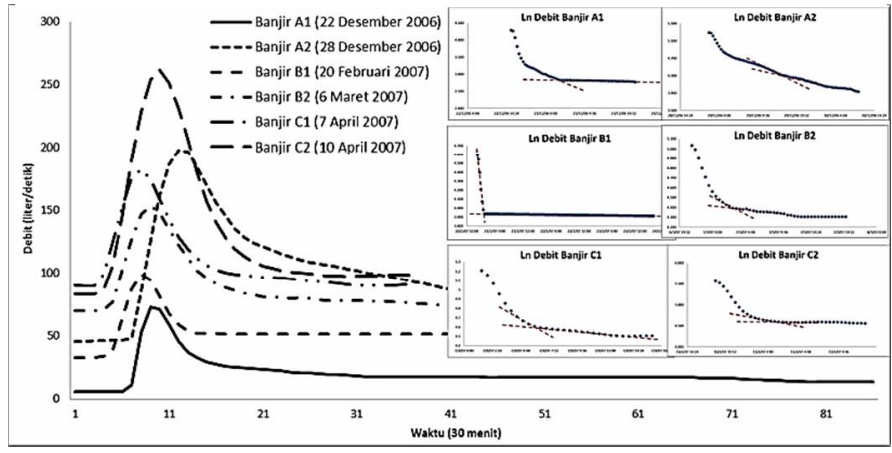

SBT Toto

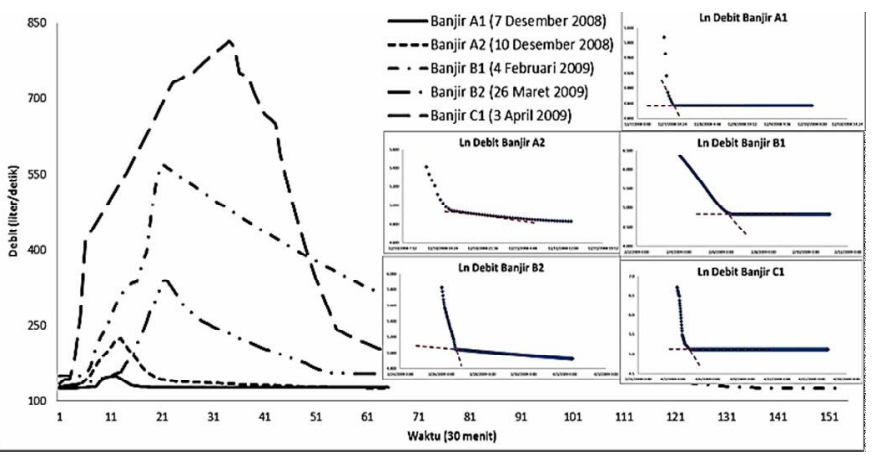

\section{SBT Ngerong}

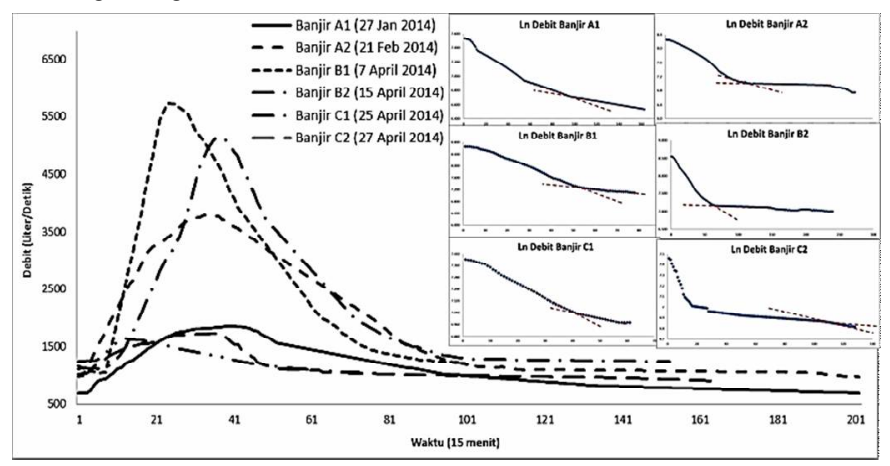

Mataair Petoyan

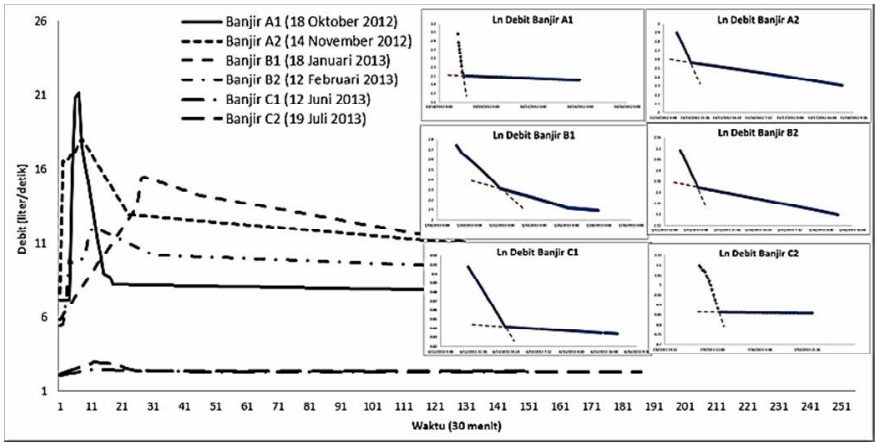

SBT Ngreneng

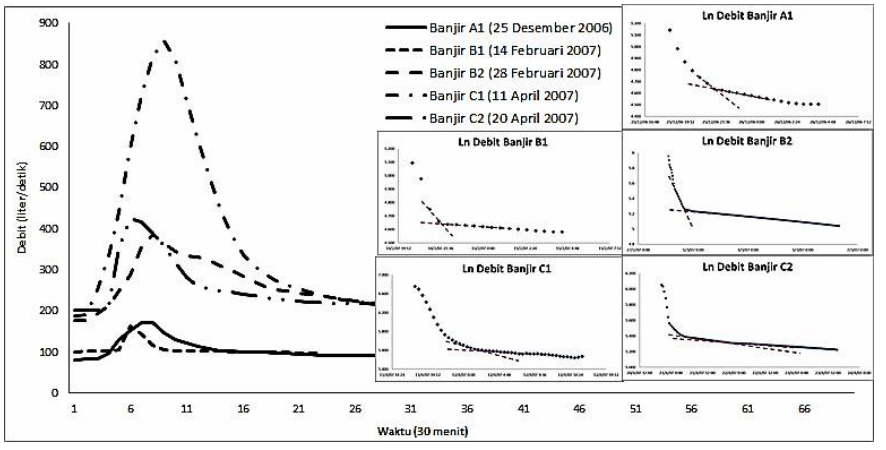

Gambar 4. Hidrograf aliran banjir terpilih dari tiap lokasi penelitian 
Citation: PIT IGI ke-17, UNY, Jogjakarta, 15 Nov 2014

Tabel 4. Karakteristik parameter hidrograf dan persentase aliran dasar

\begin{tabular}{llcccccc}
\hline \multirow{2}{*}{ Mataair dan SBT } & $\begin{array}{c}\text { Hidrograf Banjir } \\
\text { yang diukur }\end{array}$ & \multicolumn{3}{c}{ Rerata Waktu (Jam) } & \multicolumn{3}{c}{ \% Baseflow Musim Hujan } \\
\cline { 3 - 8 } & Tp & $\mathbf{T}_{\mathbf{b}}$ & $\mathbf{T}_{\text {event }}$ & Awal & Tengah & Akhir \\
\hline M ataair Beton & 23 Banjir & 12.9 & 193.4 & 154 & 48.22 & 51.77 & 46.94 \\
M ataair Petoyan & 10 Banjir & 3.6 & 9.3 & 12.9 & 40.36 & 22.67 & 39.56 \\
SBT Gilap & 16 Banjir & 3 & 36 & 37.56 & 52.78 & 55.68 & 72.12 \\
SBT Ngreneng & 8 Banjir & 4.5 & 16.8 & 56.12 & 45.10 & 48.75 & - \\
SBT Seropan & 7 Banjir & 83.6 & 619.2 & 702.85 & - & 70.47 & 67.09 \\
SBT Toto & 7 Banjir & 14.4 & 910 & 924.28 & 73.09 & 66.64 & 72.65 \\
SBT Bribin & 12 Banjir & 5.5 & 36 & 41.45 & 88.79 & 87.13 & 97.27 \\
SBT Ngerong & 13 Banjir & 10.25 & 20.54 & 30.77 & 50.46 & 57.26 & 48.14 \\
\hline Sumber : Hasil analisis data primer dan sekunder(2014) & & & & &
\end{tabular}

Berdasarkan parameter waktu debit menuju puncak banjir (Tp) dan Waktu dari debit puncak menuju aliran dasar $\left(T_{b}\right)$ pada Tabel 4, tampak bahwa Gua Gilap yang terletak pada SBT Bribin bagian hulu mempunyai respon yang paling cepat terhadap hujan ( $T p=3$ jam), karena letaknya berada di bagian hulu. Diikuti oleh Mataair Petoyan ( $\mathrm{Tp}=3.6$ jam) dengan rentang debit yang signifikan (7-44 liter/detik). M eskipun respon terhadap input cepat, Gua Gilap memiliki kapasitas melepaskan air yang lebih lama dibanding Gua Ngreneng $\left(T_{b}=16.8\right.$ jam), hal ini mengindikasikan bahwa Gua Ngreneng mempunyai sifat akuifer yang lebih cepat melepaskan komponen aliran dasar (diffuse) dan fungsi Gua Ngreneng sebagai pengatus aliran permukaan langsung (point recharge) dari cekungan-cekungan di sekitarnya.

Gua Bribin memiliki lorong gua paling panjang diantara yang lain sekitar 3.900 meter, berpengaruh pada cepatnya konsentrasi aliran (point recharge dan shaft flow) yang masuk dari daerah tangkapan sekitarnya sehingga memiliki respon yang cepat terhadap hujan ( $\mathrm{Tp}=5.5 \mathrm{jam}$ ), namun demikian kapasitas akuifer dalam melepaskan aliran dasar sama dengan Gua Gilap yang berada di bagian hulu ( $\mathrm{Tb}=36$ jam) dan lebih baik daripada Gua Ngerong.

Gua Ngerong merupakan kenampakan endokarst paling menonjol di Karst Rengel. memiliki respon terhadap kejadian hujan dan kapasitas akuifer dalam melepaskan air yang tergolong cepat $(\mathrm{T} p=10.25 \mathrm{jam} ; \mathrm{Tb}=20.54 \mathrm{jam})$. Fakta ini dikontrol oleh morfologi permukaan berupa point recharge doline dan sinkhole di daerah tangkapan Gua Ngerong yang berkontribusi besar dalam menambah aliran conduit saat banjir, model imbuhan airtanahnya pada saat musim hujan didominasi oleh internal runoff yaitu aliran permukaan dari air hujan tertampung di cekungan (doline) dan masuk ke akuifer karst melalui ponor Hal ini berbeda dengan karakteristik akuifer di Gua Seropan, Toto dan Mataair Beton yang memiliki respon terhadap hujan cukup lama ( $T p=83.6$ jam; 14.4 jam; dan 12.9 jam), tipe imbuhan airtanah khususnya di Seropan lebih didominasi dengan diffuse infiltration yaitu air hujan yang jatuh di permukaan karst terinfiltrasi melalui pori-pori tanah melalui fracture dan matrix. kapasitas akuifer dalam melepaskan simpanan air pada Seropan, Toto dan Beton ini didominasi oleh aliran diffuse yang lambat sehingga memiliki kontribusi besar dalam penyediaan debit SBT Bribin saat musim kemarau. 
Kapasitas simpanan aliran dasar paling besar adalah Gua Bribin. Hal ini ditunjukkan dengan persentase baseflow pada saat musim penghujan berkisar antara 87-97\%, saat awal musim penghujan air yang terinfiltrasi pada zone epikarst terlebih dulu memenuhi kapasitas lengas tanah, sehingga aliran dasar berkontribusi sebesar $88 \%$ terhadap total aliran, sedangkan pada akhir musim penghujan akuifer memiliki kapasitas simpanan air dalam jumlah yang cukup besar, diikuti tipe imbuhan melalui ponor dan cekungan (internal runoff) tidak memiliki kontribusi yang cukup signifikan karena sedikitnya intensitas hujan yang terjadi, sehingga saat banjir terjadi, tipe aliran didominasi oleh persentase aliran dasar sebesar $97 \%$. Selain faktor tersebut, infiltrasi diffuse melalui zone vadose dari daerah tangkapan bagian hulu dan tengah terkonsentrasi secara lateral ke daerah tangkapan Gua Bribin yang berada di bagian hilir sistem SBT Bribin-Baron menambah pasokan aliran dasar yang sangat besar untuk kebutuhan di musim kemarau.

\section{Variasi Temporal Derajat Karstifikasi $\left(D_{k}\right)$}

Hasil analisis derajat karstifikasi berdasarkan metode Rashed (2012) yang diformulasikan dalam Rumus 5 menghasilkan tingkat karstifikasi yang berbeda pada tiap mataair dan sungai bawah tanah baik pada saat awal, pertengahan dan akhir musim penghujan (Tabel 5). Pada saat awal musim penghujan, derajat karstfikasi akuifer paling tinggi berada di Gua Gilap dan Mataair Beton (karstified aquifer). Gua Gilap dan Mataair Beton yang mewakili bagian hulu sistem SBT Bribin memiliki beberapa point recharge yang berdekatan dengan saluran conduit gua, serta tingginya intensitas perkolasi air hujan pada zona vadose yang tidak sebegitu dalam menyebabkan rekahan fissures lebih dominan. Mataair Beton memiliki ciri rising limb yang ekstrim dan meningkat tajam saat terjadi banjir namun diimbangi dengan lambatnya akuifer dalam melepaskan simpanan air. Mataair Petoyan, Sungai bawah tanah Bribin, Ngreneng, Seropan, Toto dan Ngerong saat awal musim penghujan memiliki derajat karstifikasi dominasi diffuse (Darcian aquifer) karena saat awal hujan, air yang terinfiltrasi masih memenuhi simpanan air dalam lengas tanah dan epikarst, belum sepenuhnya menjadi total aliran dalam sungai bawah tanah.

Pada pertengahan musim penghujan, kapasitas epikarst dalam menyimpan airtanah sebagian besar telah terpenuhi, sehingga saat hujan terjadi dengan intensitas dan kurun waktu tertentu terjadi kelebihan kapasitas simpanan yang mengakibatkan sebagian besar air menjadi aliran permukaan ataupun aliran cepat (quickflow/aliran conduit) melalui sungai bawah tanah dan mataair.Hampir seluruh mataair dan sungai bawah tanah di lokasi penelitian pada pertengahan musim penghujan ini mencirikan derajat karstifikasi yang semakin meningkat seperti Mataair Beton (partially and highly karstified aquifer); Petoyan, Bribin, Ngreneng, dan Ngerong (partially karstified aquifer).

Pada akhir musim penghujan, derajat karstifikasi secara keseluruhan mengalami penurunan secara dominan berupa darcian aquifer.Intensitas hujan yang semakin berkurang berpengaruh pada semakin besarnya kapasitas aquifer untuk melepaskan simpanan airnya secara bertahap. Saat hidrograf banjir terjadi pada akhir musim penghujan ini aliran diffuse sudah mendominasi sebagian besar dari persentase total aliran. Karakteristik hidrograf di akhir musim hujan mengindikasikan kapasitas mataair dan sungai 
bawah tanah untuk memenuhi aliran dasar selama musim kemarau hingga tiba musim hujan berikutnya.

\section{Variasi Spasial Derajat Karstifikasi $\left(D_{k}\right)$}

Derajat karstifikasi secara lokal dalam satu kawasan karst dari hasil penelitian ini dapat dibedakan antara perkembangan karstifikasi di bagian hulu dan di bagian hilir.Istilah hulu dan hilir dalam penelitian ini untuk memudahkan pemahaman variasi spasial dalam satu sistem sungai bawah tanah di akuifer karst. Ruang lingkup yang lebih luas, nantinya akan dapat dibedakan derajat karstifikasi antara di Karst Gunung Sewu di bagian selatan Pulau Jawa dengan Karst Rengel di bagian selatan Jawa.

Didasari pada konsep awal, Konsep zona hidrologi di akuifer karst dapat dibedakan antara zona tidak jenuh (unsaturated zone) dan zona jenuh (saturated zone), namun istilah "unsaturated" dan saturated" ini jarang dipakai dalam istilah karst karena memiliki istilah yang sama dengan tingkat kejenuhan kimiawi, sehingga secara umum dipakai istilah Zona Vadose yaitu zona diatas muka air tanahdan Zona Phreatik yaitu zona dibawah muka air tanah (Ford and William, 2007). Air di zona vadose mengalami infiltrasi dan perkolasi ke bawah oleh daya grafitasi, saat proses ini akan banyak terjadi proses pelarutan secara vertikal dan lambat laun terjadi rekahan hingga menjadi conduit (ponor dan shaft). Ketika air telah mencapai muka air tanah, aliran dikontrol oleh ketinggian dan tekanan, air di zona phreatic ini mengalir mengikuti gradient hidraulik menuju outlet yang berada di lembah terdekat (Audra and Palmer, 2013). Secara lebih luas, konsep pelarutan secara vertikal akan banyak terjadi di daerah tangkapan (recharge area) dengan indikasi banyak ditemukan ponor (sinking stream), doline, dan cekungan-cekungan lainnya. Pelarutan secara horizontal searah dengan gradient hidraulik akan banyak terjadi pada daerah hilir dengan indikasi rekahan-rekahan conduit lateral ataupun lorong-lorong gua memiliki dimensi ukuran yang lebih besar seiring dengan semakin besarnya aliran sungai bawah tanah.

Daerah hulu dari sistem SBT Bribin di Karst Gunung Sewu dalam penelitian ini diwakili oleh Gua Gilap dan Mataair Beton, dan daerah hilir diwakili oleh Gua Seropan, Toto, dan Bribin, sedangkan Gua Ngreneng meskipun dianggap sebagai bocoran dari sistem SBT Bribin, kita asumsikan sebagai daerah bagian tengah. Mataair Petoyan memiliki sistem yang berbeda dengan SBT Bribin, diindikasikan memiliki derah imbuhan yang lebih sempit dan terbatas.Karst Rengel hanya dapat diwakili oleh Gua Ngerong sebagai daerah hilir dan menjadi salah satu outlet sistem sungai bawah tanah di Karst Rengel.

Derajat karstifikasi di bagian hulu yang dalam penelitian ini diwakili oleh Gua Gilap dan Mataair Beton memiliki derajat karstifikasi paling tinggi (Karstified aquifer hingga highly karstified aquifer) saat awal dan pertengahan musim penghujan. Hal ini dipengaruhi oleh banyaknya aliran air permukaan setelah kejadian hujan yang masuk ke dalam sistem jaringan sungai bawah tanah melalui ponor (swallet hole) dari cekungan-cekungan di sekitarnya. Namun hal ini juga diimbangi dengan tingginya kapasitas simpanan akuifer dan sistem melepaskan air yang sifatnya lambat dan perlahan.

Bagian hilir yang diwakili oleh SBT Bribin, Seropan dan Toto memiliki derajat karstifikasi yang rendah (Darcian aquifer)dengan tipe imbuhan dominan diffuse. Hal ini karena sedikitnya aliran permukaan yang masuk melalui proses internal runoffdan sebagian besar 
aliran bawah tanah berasal dari pasokan sistem SBT Bribin bagian tengah dan hulu.Kapasitas simpanan akuifer sangat tinggi dengan sistem pelepasan airnya yang bersifat sangat lambat.

Mataair Petoyan mewakili sistem sungai bawah tanah yang berbeda, tingkat karstifikasinya didominasi oleh aliran Diffuse namun saat musim penghujan banyak mendapatkan imbuhan dari ponor dan rekahan di sekitarnya. Kapasitas simpanan akuifer dan persentase aliran dasar paling rendah diantara yang lain mengindikasikan bahwa daerah imbuhan mataair ini tidak terlalu luas.

Bagian hilir Karst Rengel yang diwakili oleh SBT Ngerong memiliki derajat karstifikasi yang didominasi oleh aliran diffuse (Darcian aquifer). Tipe imbuhan saat musim hujan banyak dipengaruhi oleh tipe internal runoff dimana air permukaan yang berada di doline masuk melalui ponor dan gua yang secara tidak langsung memiliki hubungan dengan sistem jaringan sungai bawah tanah Ngerong.Kapasitas simpanan akuifernya tinggi dengan sistem pelepasan airnya yang bersifat perlahan.

Secara umum, Derajat karstifikasi antara di Kawasan Karst Gunung Sewu dan Karst Rengel sama-sama berada pada tahap Darcian Aquiferyang dominan alirannya bersifat diffusedengan kapasitas simpanan akuifer yang tinggi dan sistem pelepasan airnya yang lambat, namun jika dapat diistilahkan disini, Karst Rengel merupakan Darcian aquifer tahap 1 (muda) sedangkan Karst Gunung Sewu masuk dalam Darcian aquifer tahap 2 (tua) karena dilihat dari kenampakan eksokarst dan endokarstnya Karst Gunung Sewu memiliki keragaman yang lebih kompleks. Karst Rengel di bagian hilir hanya memiliki Gua Ngerong sebagai satu-satunya jaringan sungai bawah tanah yang sudah berkembang, sedangkan di Karst Gunung Sewu bagian hilir telah banyak ditemukan Gua dan jaringan sungai bawah tanah lainnya yang mencirikan kompleksnya kenampakan endokarst di kawasan ini.Karakteristik imbuhan, kapasitas simpanan akuifer dan persentase aliran dasar dari tiap lokasi penelitian telah dirangkum pada Tabel 6.

\section{Kesimpulan}

Hidrograf aliran dari mataair dan sungai bawah yang terdapat dalam suatu kawasan karst dapat menjadi parameter dalam menentukan derajat karstifikasi akuifer. Parameter hidrograf yang digunakan antara lain debit mataair, bentuk hidrograf, waktu kejadian hidrograf $\left(T_{\text {event }}\right)$, waktu dari debit dasar menuju debit puncak (time to peak), waktu dari debit puncak menuju aliran dasar (time to baseflow). Berdasarkan karakteristik hidrografnya akan dapat dilakukan analisis awal terkait tipe imbuhan airtanah, besar sedikitnya kapasitas simpanan dan sifat pelepasan air oleh akuifer karst.

Analisis hidrograf yang dikemukakan oleh Rashed (2012) telah dicoba untuk diterapkan di Karst Gunung Sewu dan Karst Rengel, Tuban pada periode musim penghujan, sehingga dapat diidentifikasi secara spasial dan temporal perbedaan derajat karstifikasi yang terjadi pada kedua kawasan karst tersebut. Secara temporal terdapat perbedaan derajat karstifikasi antara saat awal, pertengahan, dan akhir musim penghujan. Pada awal musim penghujan bertipe darcian aquifer dan meningkat menjadi partially hingga karstified aquifer saat pertengahan musim penghujan, dan menurun kembali menjadi darcian aquifer saat akhir musim penghujan. Hal ini terkait dengan pemenuhan kapasitas simpanan air pada 
zona vadose terlebih dulu saat awal musim penghujan, kapasitas simpanan telah mencapai titik jenuh pada pertengahan musim dan mulai melepaskan simpanan air saat musim kemarau.

Secara spasial terdapat perbedaan derajat karstifikasi antara di bagian hulu dan di bagian hilir dari satu sistem jaringan sungai bawah tanah. Bagian hulu yang diwakili oleh Mataair Beton dan Gua Gilap memiliki derajat karstifikasi yang lebih tinggi (Partially dan Karstified aquifer)karena banyaknya rekahan dan ponor yang berhubungan langsung dengan jaringan sungai bawah tanah, sedangkan bagian hilir yang diwakili oleh Gua Bribin, Seropan, Toto, dan Ngerong memiliki derajat karstifikasi yang lebih rendah (Darcian aquifer). Karst Gunung Sewu dan Karst Rengel keduanya memiliki derajat karstifikasi tipe Darcian aquifer yang dominan sifat alirannya diffuse, namun Karst Rengel berada pada darcian aquifer tahap 1 (muda) sedangkan Karst Gunung Sewu berada pada darcian aquifer tahap 2 (tua). Sementara itu, perhitungan derajat karstifikasi pada saat banjir pada puncak musim hujan menunjukan bahwa karstifikasi di Karst Gunung Sewu telah lebih berkembang pada tahap lanjut dibanding dengan Karst Rengel. Hal ini terlihat pula pada kenampakan morfologi endokarst dan eksokarst Karst Gunung Sewu yang lebih kompleks dibandingkan dengan Karst Rengel.

\section{Daftar Pustaka}

Adji, T. N. 2010. Spatial and Temporal Variation of Hydrogeochemistry and Karst Flow Properties to Characterize Karst Dynamic System in Underground River, Gunung Kidul Regency, DIY Province Java, Indonesia. Dissertation Geography study program. Graduate School of Geography, Gadjah Mada University, Yogyakarta.

Adji, T.N., 2005, Agresivitas Airtanah Karst Sungai Bawah Tanah Bribin, Gunung Sewu, Indonesian Cave and Karst Journal, Vol. 1 No1, HIKESPI

Adji, T.N. 2012, Wet Season Hydrochemistry of Bribin River in Gunung Sewu Karst, Indonesia, Environmental Earth Sciences, Vol. 67:1563-1572 pp

Adji, T.N., 2010. Variasi Spasial-Temporal Hidrogeokimia dan Sifat Aliran Untuk Karakterisasi Sistem Karst Dinamis di Sungai Bawah Tanah Bribin, Kabupaten Gunung Kidul, DIY, Disertasi, Fakultas Geografi, Universitas Gadjah Mada, Yogyakarta

Adji, T.N., 2011. Pemisahan aliran dasar bagian hulu Sungai Bribin pada aliran Gua Gilap, di Karst Gunung Sewu, Gunung Kidul, Yogyakarta, Jurnal Geologi Indonesia, Vol. 6 No. 3 September 2011

Adji, T.N., Hendrayana, H., Sudarmadji, E., Woro, S, 2009, Diffuse Flow Separation Within Karst Underground River at Ngreneng Cave, Proceeding of International Conference Earth Science and Technology, 6-7 Aug 2009, Yogyakarta

Adji, T.N., Misqi, M., 2010, The Distribution of Flood Hydrograph Recession Constant for Characterization of Karst Spring and Underground River Flow Components Releasing Within Gunung Sewu Karst Region, Indonesian Journal of Geography, XLII(1)

Audra, P., and Palmer, A.N.,2013.The vertical dimension of karst: controls of vertical cave pattern. In:Shroder,J.(Editorinchief),Frumkin,A.(Ed.),Treatise onGeomorphology.AcademicPress,SanDiego,CA,vol.6,KarstGeomorphology,pp.186-206.

Baena, CL. B. Andreo, J. Mudry, F. Carrasco cantos. 2009. Groundwater temperature and electrical conductivity as tools to characterize flow patterns in carbonate aquifers: The Sierra de las Nieves karst aquifer, Southern Spain. Hydrogeology Journal 17:843-853.

Bemmelen, R.W van. 1949. The Geology of Indonesia (2 vols). Gtv Print Office, The Hague

Bonacci, O. 1993. Karst springs hydrographs as indicators of karst aquifers. Hydrological Sciences 38 (1) : 51-62. 
Brunsch A, Adji, TN, Stoffel D, Ikhwan M, Oberle P, Nestmann F (2011) Hydrological assessment of a karst area in Southern Java with respect to climate phenomena, Proceeding of Asian Trans-Disciplinary Karst Conference, Yogyakarta

Daoxian, Y. 2013. Variations of karst geomorphology over geoclimatic gradients. In: Shroder, J. (Editor in Chief), Frumkin,A.(Ed.), Treatise on Geomorphology. San Diego, CA: Academic Press. Vol. 6, Karst Geomorphology, pp 319-326.

Dreiss, S.J., 1989. Regional scale transport in a karst aquifers: linear systems and time moment analysis. Water Resources Research. 25 (1) pp 126-134.

Ford, D., Williams, P. 2007. Karst Hydrogeology and Geomorphology. John Wiley \& Sons, Ltd.

Haryono, E. 2008. Model perkembangan karst berdasarkan morfometri jaringan lembah di Karangbolong, Gunungsewu, Blambangan dan Rengel. Disertasi tidak dipublikasikan. Program Pascasarjana Fakultas Geografi, Universitas Gadjah Mada.

Haryono, E. dan Adji, T.N. 2004. Geomorfologi dan Hidrologi Karst. Yogyakarta: Kelompok Studi Karst, Fakultas Geografi, Universitas Gadjah Mada

Haryono, E., and Day, Mick., 2004. Landform differentiation within the Gunung Kidul Kegelkarst, Java, Indonesia.Journal of Cave and Karst Studies, Vol. 66, no. 2, pp 62-69.

Haryono, E., Suratman W., Sriyono, Soenarso, S. 2001. Pemetaan zonasi kawasan karst di Jawa Timur bagian utara (Kabupaten Tuban).Penelitian kerjasama antara Dinas Pertambangan Propinsi Jawa Timur dengan Fakultas Geografi UGM .

Kresic, N. and Ognjen Bonacci. 2010. Spring Discharge Hydrograph. In Kresic, N. and Zoran Stevanovic. 2010. Groundwater Hydrology of Springs: engineering, theory, management, and sustainability. Butterworth-Heinemann.

Kresic, N. and Zoran, S.. 2010. Groundwater Hydrology of Springs: engineering, theory, management, and sustainability. Butterworth-Heinemann

Kusumayudha, S.B., 2005. Hidrogeologi Kars dan Geometri Fraktal di Daerah Gunungsewu. Adicita Karya Nusa, Yogyakarta.

Lastennet, R. and M udry, J., 1997. Role of karstification and rainfall in the behavior of heterogeneous karst system.Enviromental Geology 32 (2) September 1997: Springer-Verlag, pp 114-123.

MacDonalds dan Partners. 1984. Greater Yogyakarta-Groundwater Resources Study. 3C: Cave Survey, Yogyakarta. Directorate General of Water Resources Development Project (P2AT).

Misqi, M. 2010. Analisis konstanta resesi sungai bawah tanah untuk karakterisasi pelepasan komponen akuifer karst (studi kasus mataair beton, sungai bawah tanah seropan, dan sungai bawah tanah toto,Kab Gunung Kidul, Propinsi DIY).Skripsi tidak dipublikasikan, Fakultas Geografi, Universitas Gadjah M ada.

Mohammadi, Z and A. Shoja. 2013. Effect of annual rainfall amount on characteristics of karst spring hydrograph. Carbonate Evaporites

Nguyet, Vu Thi Minh. 2006. Hydrogeological Characterisation and Groundwater Protection of Tropical Mountainous Karst areas in NW Vietnam. VUB-Hydrology series Nr 48. Brussel: Departement of Hydrology and Hydraulic engineering.

Raeisi, E. and Karami, G. 1997. Hydrochemographs of berghan karst spring as Indicators of aquifer characteristics. Journal of Cave and Karst Studies 59(3): 112-118.

Rashed, Khaled A. 2012. Assessing degree of karstification: a new method of classifying karst aquifers.Sixteenth International Water Technology Conference, IWTC 16 2012, Istanbul, Turkey

Shuster, E. T. and White, W. B. 1971. Seasonal fluctuations in the chemistry of limestone Springs: a possible means for characterizing Carbonate aquifers. Journal of hydrology 14: 93-128

White, W. B. and Elizabeth L. W. 2003. Conduit fragmentation, Cave patterns, and the localization of karst groundwater basins: The Appalachians as test case. Speleogenesis and evolution of karst aquifer I (2) : 1-15 
Citation: PIT IGI ke-17, UNY, Jogjakarta, 15 Nov 2014 
Citation: PIT IGI ke-17, UNY, Jogjakarta, 15 Nov 2014

Tabel 5. Perhitungan Derajat Karstifikasi pada awal, tengah, dan akhir musim penghujan di lokasi penelitian

\begin{tabular}{|c|c|c|c|c|c|c|c|c|c|c|c|c|c|c|c|c|c|c|c|}
\hline \multirow{2}{*}{$\begin{array}{l}\text { Mataair dan Sungai } \\
\text { Bawah Tanah }\end{array}$} & \multirow{2}{*}{\begin{tabular}{|c|} 
Hidrograf \\
Banjir
\end{tabular}} & \multicolumn{6}{|c|}{ Awal } & \multicolumn{6}{|c|}{ Tengah } & \multicolumn{6}{|c|}{ Akhir } \\
\hline & & Qmax & Qmin & T peak & \begin{tabular}{|l|} 
Tevent \\
\end{tabular} & Dk & Klasifikasi & Qmax & Qmin & T peak & \begin{tabular}{|l|} 
Tevent \\
\end{tabular} & Dk & Klasifikasi & Qmax & $Q \min$ & Tpeak & \begin{tabular}{|l|} 
Tevent \\
\end{tabular} & Dk & Klasifikasi \\
\hline \multirow{2}{*}{ Beton } & 1 & 7216.54 & 2322.26 & 8 & 87 & 33.79 & Karstified aquifer & 6478.12 & 1700.87 & 7.5 & 21.5 & 10.92 & Partially Karstified aquifer & 2433.12 & 989.29 & \begin{tabular}{|r|}
2 \\
\end{tabular} & \begin{tabular}{r|}
7 \\
\end{tabular} & 8.61 & Darcian aquifer \\
\hline & 2 & 7315.67 & 2234.66 & 4 & 58.5 & 47.88 & Karstified aquifer & 11111.68 & 1818.73 & 2.5 & 46 & 112.42 & Highly Karstified aquifer & 2207.30 & 580.97 & 4.5 & 14 & 11.82 & Partially Karstified aquifer \\
\hline \multirow{2}{*}{ Petoyan } & 1 & 21.16 & 7.16 & 2 & 7 & 10.34 & Darcian aquifer & 15.48 & 5.86 & 14 & 77 & 14.54 & Partially Karstified aquifer & 2.48 & 2.09 & 5 & 23.5 & 5.57 & Darcian aquifer \\
\hline & 2 & 18.03 & 7.63 & 4 & 11 & 6.50 & Darcian aquifer & \begin{tabular}{|c|}
12.07 \\
\end{tabular} & 5.45 & 6 & 15 & 5.54 & Darcian aquifer & 2.99 & 2.20 & 6 & 13 & 2.95 & Darcian aquifer \\
\hline \multirow{2}{*}{ Bribin } & 1 & 1673.90 & 1611.75 & 7 & 46 & 6.82 & Darcian aquifer & 2113.17 & 1892.20 & 2 & 25.5 & 14.24 & Partially karstified aquifer & 1936.13 & 1851.93 & 4 & 17.5 & 4.57 & Darcian aquifer \\
\hline & 2 & 2445.62 & 1782.41 & 8 & 35 & 6.00 & Darcian aquifer & $\begin{array}{l}1973.97 \\
\end{array}$ & 1756.80 & 3.5 & 11.5 & 3.69 & Darcian aquifer & 1930.03 & 1834.95 & 3.5 & 10.5 & 3.16 & Darcian aquifer \\
\hline \multirow{2}{*}{ Gilap } & 1 & 72.70 & 5.34 & 2.5 & 14.5 & 78.91 & Highly karstified aquifer & 98.70 & 32.44 & 3 & 6 & 6.09 & Darcian aquifer & 182.64 & 89.44 & 3 & 7.5 & 5.11 & Darcian aquifer \\
\hline & 2 & 197.92 & 46.13 & 3.5 & 20.5 & 25.13 & \begin{tabular}{|l|} 
Karstified aquifer \\
\end{tabular} & 153.45 & 70.41 & 3 & 9 & 6.54 & Darcian aquifer & 261.61 & 82.82 & 4 & 11.5 & 9.08 & Darcian aquifer \\
\hline \multirow{2}{*}{ Ngreneng } & 1 & 170.93 & 83.81 & 3 & 6 & 4.08 & Darcian aquifer & 163.05 & \begin{tabular}{c|c|}
101.87 \\
\end{tabular} & 2 & 3.5 & 2.80 & Darcian aquifer & 856.09 & 186.83 & 4.5 & 13 & 13.24 & Partially karstified aquifer \\
\hline & 2 & \multicolumn{5}{|c|}{ tidak tersedia data } & & 385.01 & 176.45 & 3.5 & 17 & 10.60 & Partially karstified aquifer & 424.33 & 201.94 & 2 & 26.5 & 27.84 & Karstified aquifer \\
\hline \multirow{2}{*}{ Seropan } & 1 & 927.30 & 834.42 & 6 & 10 & 1.85 & Darcian aquifer & 1044.74 & 880.63 & 6.5 & 23 & 4.20 & Darcian aquifer & 1184.54 & 845.17 & 3 & \begin{tabular}{c|c}
45.5 \\
\end{tabular} & 21.26 & Karstified aquifer \\
\hline & 2 & 1100.00 & 890.76 & 5.5 & 13.5 & 3.03 & Darcian aquifer & \multicolumn{5}{|c|}{ tidak tersedia data } & & \multicolumn{5}{|c|}{ tidak tersedia data } & \\
\hline \multirow{2}{*}{ Toto } & 1 & 150.51 & 124.49 & 6 & 10 & 2.02 & Darcian aquifer & 569.66 & 149.77 & \begin{tabular}{r|}
6.5 \\
\end{tabular} & 61.5 & 35.99 & Karstified aquifer & 814.02 & 133.26 & \begin{tabular}{|l|}
17 \\
\end{tabular} & \begin{tabular}{|r|}
41.5 \\
\end{tabular} & 14.91 & Partially karstified aquifer \\
\hline & 2 & 223.85 & 125.03 & 6.5 & 17 & 4.68 & Darcian aquifer & 338.00 & 127.36 & 10 & 27 & 7.17 & Darcian aquifer & \multicolumn{5}{|c|}{ tidak tersedia data } & \\
\hline \multirow{2}{*}{ Ngerong } & 1 & 1860.17 & 689.60 & 9.75 & 33.5 & 9.27 & Darcian aquifer & 5735.30 & \begin{tabular}{ll|}
1041.97 \\
\end{tabular} & 4.75 & 17.75 & 20.57 & Karstified aquifer & 1639.31 & 1252.80 & 2.25 & \begin{tabular}{|l|}
12.25 \\
\end{tabular} & 7.12 & Darcian aquifer \\
\hline & 2 & 3792.71 & 981.74 & 8.5 & 26.75 & 12.16 & Partially karstified aquifer & 5148.01 & 1117.27 & 8 & 24 & 13.82 & Partially karstified aquifer & 1749.44 & 1039.75 & 8.75 & 27.75 & 5.34 & Darcian aquifer \\
\hline
\end{tabular}

Tabel 6.Karakteristik Derajat Karstifikasi akuifer karst berdasarkan parameter hidrograf banjir terpilih di lokasi penelitian

\begin{tabular}{|c|c|c|c|c|c|}
\hline $\begin{array}{l}\text { Mataair \& Sungai } \\
\text { Bawah Tanah }\end{array}$ & Bentuk Hidrograf & Karakteristik imbuhan & Kapasitas simpanan aquifer & Persentase aliran dasar & Derajat karstifikasi \\
\hline Mataair Beton & $\begin{array}{l}\text { Rising limb meningkat tajam, } \\
\text { recession limb saat awal dan akhir musim penghujan } \\
\text { menurun secara lambat, namun saat pertengahan hujan } \\
\text { menurun secara cepat }\end{array}$ & $\begin{array}{l}\text { Dominan internal runoff dari ponor } \\
\text { dan aliran permukaan di cekungan } \\
\text { (doline). }\end{array}$ & $\begin{array}{l}\text { Kapasitas simpanan pada awal dan akhir musim hujan } \\
\text { Tinggi, namun saat pertengahan musim hujan rendah } \\
\text { karena kapasitas simpanan penuh dan seluruhnya menjadi } \\
\text { aliran conduit }\end{array}$ & $\begin{array}{l}\text { Rasio bulanan tinggi (80\%), rasio pemenuhan } \\
\text { kapasitas akuifer oleh aliran dasar paling tinggi } \\
\text { pada pertengahan musim hujan (51.77\%) }\end{array}$ & Karstified aquifer \\
\hline Mataair Petoyan & $\begin{array}{l}\text { Rising limb meningkat tajam, } \\
\text { recession limb menurun secara lambat }\end{array}$ & $\begin{array}{l}\text { Dominan diffuse infiltration, diikuti } \\
\text { dengan shaft flow dari rekahan dan } \\
\text { ponor }\end{array}$ & $\begin{array}{l}\text { Kapasitas simpanan akuifer paling rendah diantara yang } \\
\text { lain. daerah imbuhan tidak terlalu luas. }\end{array}$ & $\begin{array}{l}\text { Rasio bulanan tinggi. Persentase aliran dasar } \\
\text { paling tinggi saat awal dan akhir musim } \\
\text { penghujan. }\end{array}$ & Darcian aquifer \\
\hline SBT Gilap & $\begin{array}{l}\text { Rising limb meningkat cepat, recession limb menurun secara } \\
\text { bertahap dan lambat }\end{array}$ & $\begin{array}{l}\text { Dominan internal runoff melalui ponor } \\
\text { dan rekahan fissures }\end{array}$ & Kapasitas simpanan tinggi, lebih bagus daripada Ngreneng & $\begin{array}{l}\text { Rasio bulanan tinggi }(80 \%) \text {, akhir musim } \\
\text { penghujan paling tinggi }(72 \%)\end{array}$ & Karstified aquifer \\
\hline SBT Ngreneng & $\begin{array}{l}\text { Rising limb meningkat tajam, recession limb menurun secara } \\
\text { cepat. }\end{array}$ & $\begin{array}{l}\text { Dominan internal runoff dari doline } \\
\text { sekitarnya }\end{array}$ & Kapasitas simpanan sedang, lebih rendah dari Gilap & $\begin{array}{l}\text { Rasio bulanan tinggi ( } 80 \%) \text {, \% baseflow paling } \\
\text { tinggi saat pertengahan musim hujan (48\%) }\end{array}$ & $\begin{array}{l}\text { Partially Karstified } \\
\text { aquifer }\end{array}$ \\
\hline SBT Seropan & $\begin{array}{l}\text { Rising limb saat awal dan pertengahan musim hujan } \\
\text { meningkat dengan sangat lambat, namun rising limb di akhir } \\
\text { musim penghujan meningkat tajam. Recession limb } \\
\text { menurun dengan sangat lambat. }\end{array}$ & Dominan Diffuse Infiltration & $\begin{array}{l}\text { Kapasitas simpanan sangat tinggi, namun saat akhir musim } \\
\text { penghujan rendah karena kapasitas simpanan sudah penuh }\end{array}$ & $\begin{array}{l}\text { Rasio bulanan tinggi (80\%), \% baseflow paling } \\
\text { tinggi saat pertengahan musim penghujan (70.4\%) }\end{array}$ & Darcian aquifer \\
\hline SBT Toto & $\begin{array}{l}\text { Rising limb meningkat secara perlahan, Recession limb } \\
\text { menurun dengan sangat lambat }\end{array}$ & Dominan Diffuse Infiltration & Kapasitas simpanan akuifer sangat tinggi & $\begin{array}{l}\text { Rasio bulanan tinggi (80\%), \% baseflow paling } \\
\text { tinggi dicapai saat awal dan akhir musim } \\
\text { penghujan }\end{array}$ & Darcian aquifer \\
\hline SBT Bribin & $\begin{array}{l}\text { Rising limb meningkat cepat, recession limb menurun secara } \\
\text { bertahap dan lambat, sama dengan Gilap }\end{array}$ & $\begin{array}{l}\text { Dominan internal runoff dan pasokan } \\
\text { dari sistem SBT Bribin hulu dan } \\
\text { tengah }\end{array}$ & Kapasitas simpanan akuifer sangat tinggi & $\begin{array}{l}\text { Rasio bulanan sangat tinggi (97-99\%), \% baseflow } \\
\text { pada akhir musim penghujan paling tinggi hingga } \\
\text { mencapai } 97 \%\end{array}$ & Darcian aquifer \\
\hline SBT Ngerong & $\begin{array}{l}\text { Rising limb meningkat cepat, namun lebih lambat dari Bribin, } \\
\text { Gilap, dan Ngreneng. Recession limb menurun secara } \\
\text { bertahap (<Nareneng) }\end{array}$ & $\begin{array}{l}\text { Dominan internal runoff dari ponor } \\
\text { dan aliran permukaan di cekungan } \\
\text { (doline). }\end{array}$ & Kapasitas simpanan tinggi & $\begin{array}{l}\text { Rasio bulanan tinggi. \% baseflow paling tinggi } \\
\text { terjadi pada pertengahan musim hujan (57\%) }\end{array}$ & Darcian aquifer \\
\hline
\end{tabular}


Citation: PIT IGI ke-17, UNY, Jogjakarta, 15 Nov 2014 